\title{
EFFECT OF THE SEASON AND THE STAGE OF LACTATION ON THE PHYSICOCHEMICAL PROPERTIES OF HOLSTEIN'S COW MILK IN TIARET, ALGERIA
}

\author{
Amina Belkhemas $^{1 *}$, Abdellatif Niar ${ }^{1}$, Bouabdellah Benallou ${ }^{2}$, Mohamed Benahmed ${ }^{1}$ \\ ${ }^{1 *}$ Nature and Life Sciences Faculty, University of Tiaret (14000), Algeria; \\ ${ }^{2}$ Farm Animal Reproduction Laboratory, Veterinary Institute, University of Tiaret (14000), Algeria; \\ *Corresponding author Amina Belkhemas, e-mail: amina.belkhemas@univ-tiaret.dz;
}

Received June 2021; Accepted July 2021; Published September 2021;

DOI: $\underline{\text { https://doi.org/10.31407/ijees11.425 }}$

\begin{abstract}
The current study aimed to determine the effect of season and lactation stages on certain physico-chemical parameters in Holstein crossbred cows in Tiaret city (Algerian west high lands). A total of 245 milk samples from 45 cows were analyzed by lactoscan SP in two seasons (spring and winter), and from different stage of lactation (early, mid and late). The results showed that all the chemical constituents were higher in the spring and lower in winter, with no significant difference. However, the season had a significant influence on milk conductivity (p $<0.05$ ). On the other hand, Fat was the only component that was highly significantly affected by the lactation stage ( $\mathrm{p}<0.001$ ). Further, there was an increase in protein, fat, SNF, and conductivity values during the progress of lactation, unlike the values of lactose and density that decrease when the lactation stage progresses.
\end{abstract}

Key words: Holstein cows, season, stage of lactation, physico-chemical parameters 